\title{
Role of the Intrarenal Renin-Angiotensin- Aldosterone System in Chronic Kidney Disease
}

\author{
Helmy M. Siragy Robert M. Carey \\ Division of Endocrinology and Metabolism, Department of Medicine, University of Virginia Health System, \\ Charlottesville, Va., USA
}

\section{Key Words}

Angiotensin - Direct renin inhibition - Aliskiren ·

Kidney disease

\begin{abstract}
The existence of local or tissue-based renin-angiotensin-aldosterone systems (RAAS) is well documented and has been implicated as a key player in the pathogenesis of cardiovascular and renal diseases. The kidney contains all elements of the RAAS, and intrarenal formation of angiotensin II not only controls glomerular hemodynamics and tubule sodium transport, but also activates a number of inflammatory and fibrotic pathways. Experimental and clinical studies have shown that the intrarenal RAAS is activated early in diabetic nephropathy, the leading cause of chronic kidney disease (CKD). Although angiotensin-converting enzyme inhibitors and angiotensin receptor blockers decrease the rate of decline in kidney function in patients with diabetic and nondiabetic nephropathy, many patients still progress to endstage renal disease or die from cardiovascular events. There is still a clear need for additional strategies to block the RAAS more effectively to reduce progression of CKD. The focus of this paper is to review the importance of the intrarenal RAAS in CKD and recent findings in renin-angiotensin biology pertinent to the kidney. We also discuss additional strategies to
\end{abstract}

inhibit the RAAS more effectively and the potential impact of direct renin inhibition on the prevention and management of CKD.

Copyright $\odot 2010$ S. Karger AG, Basel

\section{Introduction}

The importance of the renin-angiotensin-aldosterone system (RAAS) in the regulation of blood pressure and fluid and electrolyte balance has been recognized for decades. Its role in the pathogenesis of cardiorenal diseases is also widely accepted, based largely on results from clinical studies using drugs that interfere with the RAAS. The demonstration of local angiotensin II (Ang II) synthesis in numerous tissues and organs has led to the concept of local or tissue-based RAASs that are independent of but can interact with the traditional circulating RAAS [1]. These local RAASs appear to act in a paracrine/autocrine manner to regulate organ function and are involved in pathologic events associated with end-organ damage. The kidney contains all the elements of the RAAS, and intrarenal formation of Ang II independent of the circulating RAAS was first demonstrated more than 30 years ago [2]. The acknowledged importance of the intrarenal RAAS in the pathogenesis of hypertension and chronic 
kidney disease (CKD) and the clinical availability of aliskiren, a direct renin inhibitor (DRI), have stimulated renewed interest in therapeutic options to modulate the function of the RAAS. This review explores recent findings in RAAS biology as they relate to the intrarenal RAAS, the importance of the intrarenal RAAS in CKD, and the potential impact of DRIs on the prevention and management of CKD.

\section{Elements of the Intrarenal RAAS}

\section{Ang II Receptors}

Ang II acts on two major receptor subtypes, namely type $1\left(\mathrm{AT}_{1}\right)$ and type $2\left(\mathrm{AT}_{2}\right)$ Ang II receptors [3]. The $\mathrm{AT}_{1}$ receptor predominates in most tissues and mediates the classic physiologic and pathophysiologic actions of Ang II. The $\mathrm{AT}_{1}$ receptor is widely distributed among vascular, glomerular, and tubular elements of the kidney, consistent with this receptor's role in regulating renal hemodynamics, glomerular filtration, sodium reabsorption, and renin release [1]. The $\mathrm{AT}_{2}$ receptor is less abundant and has a more restricted distribution in the kidney, mainly limited to vascular elements and tubular segments, especially the proximal tubule [4]. Although a role for $\mathrm{AT}_{2}$ receptors in renal function is currently under investigation, activation of renal $\mathrm{AT}_{2}$ receptors appears to have effects that generally oppose those induced by the $\mathrm{AT}_{1}$ receptor [4].

\section{Renin}

Renin release from juxtaglomerular cells is highly regulated and is stimulated by a decrease in renal perfusion pressure, a decrease in the delivery of $\mathrm{Cl}^{-}$to the macula densa, or by sympathetic nerve stimulation via $\beta_{1}$-adrenoceptors [3]. Renin release is directly inhibited by Ang II acting through both $\mathrm{AT}_{1}$ and $\mathrm{AT}_{2}$ receptors on juxtaglomerular cells, thus constituting an Ang II-renin release negative feedback loop [3].

Renin synthesis and secretion appear to be dependent on the integrity of connexins, which are gap junction proteins involved in cell-to-cell communication [5]. The cells of the juxtaglomerular apparatus express a number of connexins including Cx40, Cx43 [5] and Cx45 [6]. Deletion of $\mathrm{Cx} 40$ or replacement of $\mathrm{Cx} 43$ [5] reduces the expected increase in renin secretion and blood pressure in a model of renal artery stenosis. In contrast, deletion of Cx45 in mice increased renin expression, plasma renin activity (PRA) and blood pressure compared to control mice [6]. Although the exact mechanism by which con- nexins regulate renin synthesis and secretion is unknown, it appears that cell-to-cell communication mediated by connexins within the juxtaglomerular apparatus is required [5].

In addition to juxtaglomerular cells, renin mRNA and protein have been found in the connecting tubule and collecting duct [7]. Unlike juxtaglomerular cells where Ang II inhibits renin release via the $\mathrm{AT}_{1}$ receptor, in the collecting duct Ang II stimulates renin expression via the $\mathrm{AT}_{1}$ receptor [8]. In animal models of diabetes [7] and Ang II-dependent hypertension [8], collecting duct prorenin and renin are upregulated. The elevated levels of prorenin observed in diabetes may derive mainly from the epithelial cells of the collecting duct [7]. During periods of juxtaglomerular renin suppression, upregulated renin produced in the distal nephron may be able to support continued intrarenal Ang II formation leading to amplification or maintenance of the hypertensive state [8].

The intrarenal RAAS is activated early in diabetes yet the exact mechanism is unknown. The discovery of GPR91, a G-protein-coupled receptor that is activated by succinate [9], may provide a link between hyperglycemia and RAAS activation. In rats, infusion of succinate increased PRA and blood pressure, both of which were attenuated by angiotensin-converting enzyme (ACE) inhibition and totally abolished by bilateral nephrectomy [9] . This may be a candidate for a pathophysiological link with diabetic nephropathy, as high levels of glucose stimulate succinate accumulation, and this directly increases renin release from isolated juxtaglomerular apparatus in vitro [10].

\section{(Pro)renin Receptor}

Prorenin, once viewed as an inactive precursor of renin, has recently received more attention in RAAS research due to the discovery of a (pro)renin receptor [11]. This receptor, which is expressed in heart, brain, placenta, liver, kidney, and brown adipose tissue [11], binds prorenin and, with lower affinity, renin [12]. When bound to this receptor, prorenin undergoes a conformational change and becomes enzymatically active without undergoing proteolysis [11]. This mechanism may contribute to local Ang II formation especially in tissues that appear to lack the renin gene, yet produce Ang II, such as the heart and blood vessel wall, and therefore must rely on renin/prorenin uptake from the circulation [12].

Activation of the (pro)renin receptor in cultured mesangial cells activates the mitogen-activated protein kinase (MAPK)-extracellular signal-regulated kinase 
Fig. 1. Multiple roles of the RAAS in the pathogenesis of chronic kidney disease. $\mathrm{ECM}=$ Extracellular matrix; NF- $\kappa \mathrm{B}=\mathrm{nu}-$ clear factor- $\kappa \mathrm{B}$; TGF- $\beta=$ transforming growth factor $\beta$.

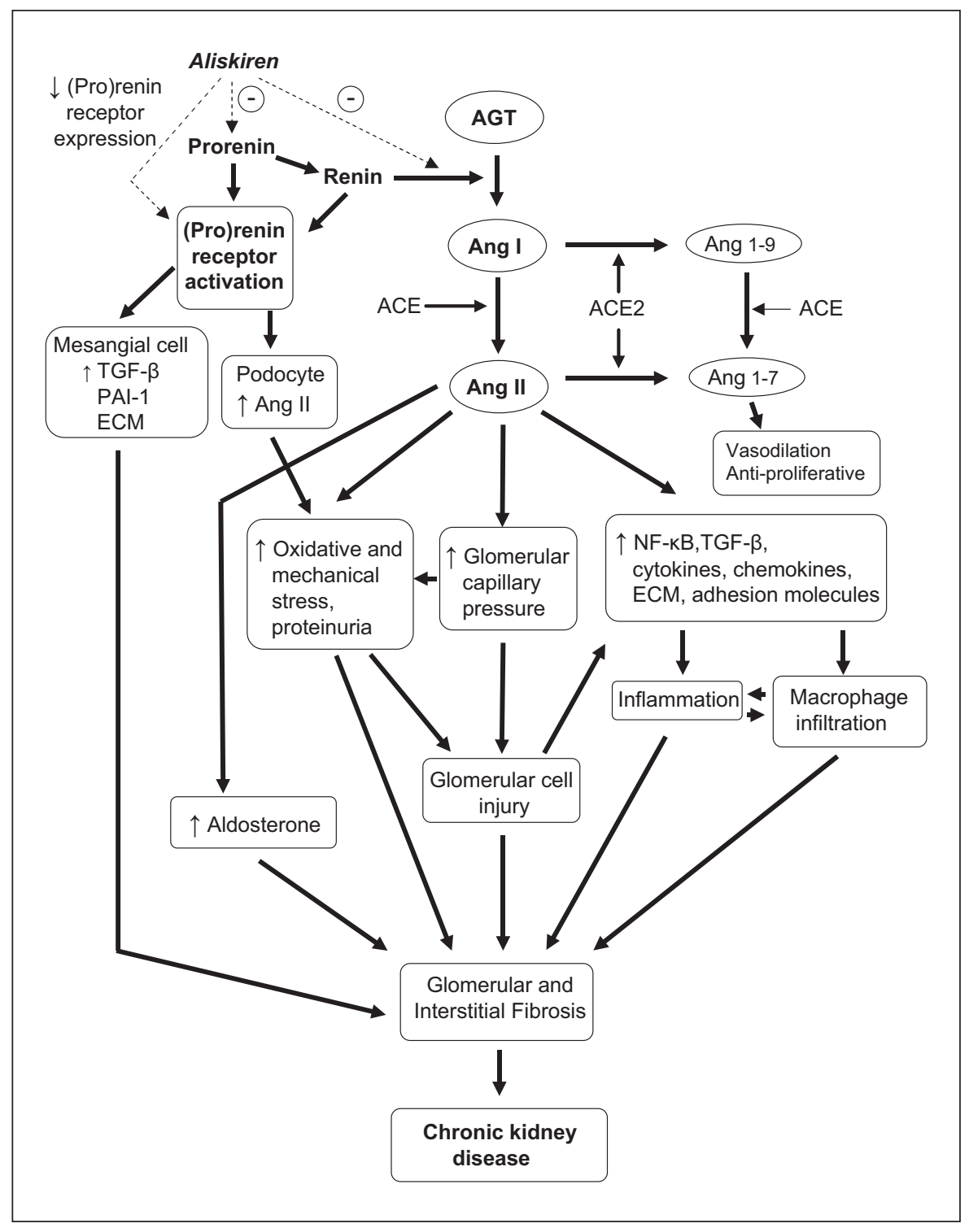

(ERK) pathway [11] and increases several profibrotic mediators, including transforming growth factor $\beta$ (TGF$\beta$ ), and plasminogen activator inhibitor-1 (PAI-1), and the extracellular matrix components, fibronectin and collagen-1 [13]. These effects occur in the presence of an ACE inhibitor or angiotensin receptor blocker (ARB) and are therefore independent of Ang II formation or action [11]. Thus, activation of the (pro)renin receptor in mesangial cells by elevated levels of prorenin, such as occur in diabetes [14], may contribute to glomerulosclerosis [13] (fig. 1).

The (pro)renin receptor has also been detected in human podocytes [15]. In these cells, prorenin treatment results in an increase in intracellular Ang II that is blocked by aliskiren. As in mesangial cells, stimulation of the (pro)renin receptor in podocytes results in the activation of the MAPK-ERK pathway. However, no increased expression of PAI- 1 or TGF- $\beta$ was detected (and thus the question mark in figure 1) [15]. Accordingly, the role of the prorenin receptor in podocytes biology remains to be determined.

Of note, excessive stimulation of the (pro)renin receptor appears to downregulate its own transcription [16], and so activation of this receptor by high levels of prorenin may be self-limiting [12]. The effects of overexpressing the (pro)renin receptor on end-organ damage in 
rats and mice are mixed [17-20], and therefore, the clinical significance of (pro)renin receptor activation independent of Ang II formation is currently unknown.

\section{Angiotensinogen}

Circulating angiotensinogen (Agt) is produced by the liver. By contrast, intrarenal Agt is synthesized in the epithelial cells of the proximal tubule, secreted into the tubular lumen, and appears in the urine [21]. Because of its molecular size, very little if any plasma Agt is filtered by the glomerulus [21]. The presence of intact Agt in the urine suggests that it is not a substrate for megalin, probably because of its size, and is not degraded to any great extent along the nephron [22]. The localization of renin in the collecting tubule [7] and the delivery of proximally produced Agt, together with the presence of ACE in the tubular fluid [21], allows for the possible formation of Ang I and Ang II in this part of the nephron, even when juxtaglomerular renin is suppressed.

In humans, urinary Agt is increased in patients with hypertension [23] and CKD [24]. Furthermore, in a small cohort of patients with type 1 diabetes and normal protein excretion, urinary Agt was elevated compared with control patients [22]. This suggests that increased urinary Agt precedes the development of proteinuria and may be a biomarker of intrarenal RAAS activation in these conditions [22-24].

\section{Angiotensin-Converting Enzymes}

In the human kidney, ACE is localized primarily to the brush border membrane of the proximal tubule, whereas in rats ACE is mainly expressed on the endothelial cells of the renal microvasculature [1] but can also be found in tubular fluid along most of the nephron [21]. In addition to the ACE pathway, Ang II can be formed from Ang I by chymase, a serine protease that is highly expressed in mast cells and in organs, such as heart and kidney [25]. Chymase-dependent Ang II formation may be at least partly responsible for 'ACE escape'. This term refers to the observation that, in a high proportion of patients chronically treated with ACE inhibitors, Ang II levels gradually return to baseline after an initial decline. This increase in Ang II formation in the presence of ACE inhibitors is likely due to a compensatory increase in PRA caused by disruption of the feedback loop by which Ang II normally inhibits renin release [3]. Under these circumstances, Ang II can be formed from Ang I by alternative, ACE-independent pathways, such as chymase, which has been shown to be upregulated in diabetic and hypertension-related nephropathies [25].
In 2000 an isoform of ACE, ACE-2, was discovered. ACE-2 is a catalytically active homolog of ACE that is not inhibited by ACE inhibitors and is abundantly expressed in the kidney, heart, and other organs [26]. ACE-2 cleaves a single residue from Ang I to generate the inactive Ang (1-9) (fig. 1). In addition, ACE-2 generates the biologically active peptide Ang (1-7) directly from Ang II [26]. Ang (1-7) appears to have actions that oppose those mediated by Ang II, including vasodilation and antiproliferative effects [27]. In the human kidney, ACE-2 is localized primarily to glomerular and tubular epithelial cells and to vascular smooth muscle cells and endothelium of intrarenal (arcuate and interlobular) arteries [28]. Glomerular ACE-2 is decreased in mouse models of diabetic nephropathy [28], and pharmacological inhibition of ACE-2 [28] or knockout of ACE-2 [29] in diabetic mouse models worsens glomerular injury and promotes albuminuria. Thus, ACE-2 may counteract the role of ACE during RAAS activation by breaking down Ang I and promoting the formation of Ang (1-7) [27].

\section{Intrarenal Aldosterone Biosynthesis}

Increasing evidence suggests that aldosterone induces oxidative stress, inflammation, and fibrosis, resulting in cardiovascular and renal injury [30]. Mineralocorticoid receptor blockers when added to ACE inhibitors or ARBs produce further decreases in proteinuria in patients with CKD [31]. With the exception of the brain, extra-adrenal synthesis of aldosterone is controversial. However, cytochrome P450 11ß2 (CYP11ß2), the enzyme responsible for the synthesis of aldosterone from deoxycorticosterone, has been reported to be present in the rat kidney, mainly in the glomerulus [32] and podocytes [33]. Upregulation of CYP11 32 was observed in a rat model of insulin-dependent diabetes $[32,33]$. Whether a similar system exists in the human kidney is unknown.

\section{$11 \beta$-Hydroxysteroid Dehydrogenase}

$11 \beta$-Hydroxysteroid dehydrogenase (11 $\beta$-HSD) is responsible for the interconversion of the corticosteroids cortisol and cortisone. There are two isozymes: 11 $\beta$-HSD1 and $11 \beta-H S D 2.11 \beta-H S D 1$ is a NADP $(\mathrm{H})$-dependent enzyme that is highly expressed in glucocorticoid target tissues such as liver but is expressed at very low levels in human kidney [34]. This isozyme is responsible for the conversion of cortisone to the active glucocorticoid cortisol. Increased expression and/or activity of $11 \beta$-HSD1 have been linked to obesity and insulin resistance [34].

$11 \beta$-HSD2 is a NAD-dependent enzyme that converts cortisol to inactive cortisone and is highly expressed in 
aldosterone-sensitive tissues, such as the kidney and colon [34]. The distribution of 11ß-HSD2 in the kidney parallels that of the mineralocorticoid receptor with the highest levels being detected in the cortical collecting duct [35]. Because cortisol and aldosterone have similar affinities for the mineralocorticoid receptor, 11ß-HSD2, by metabolizing cortisol, protects the mineralocorticoid receptor from activation by the glucocorticoid [34]. A deficiency of $11 \beta-H S D 2$, as a result of genetic mutations or the inhibition of the enzyme by glycyrrhetinic acid (present in licorice), can lead to apparent mineralocorticoid excess because of overstimulation of the unprotected mineralocorticoid receptor by cortisol. This results in hypokalemia, sodium retention, extracellular fluid volume expansion, and hypertension [36].

The effects of Ang II on 11ß-HSD activity are variable. In vitro studies have reported an inhibitory effect of Ang II on $11 \beta-H S D 2$ activity via the $\mathrm{AT}_{2}$ receptor [37], while infusion of Ang II in humans increased 11 $\beta$-HSD2 activity [38]. Because Ang II is a potent stimulator of reactive oxygen species [30], it could also affect $11 \beta-H S D$ activity by altering the availability of $\mathrm{NADP}(\mathrm{H})$ and/or NAD.

\section{Role of the Intrarenal RAAS in CKD}

The importance of the RAAS in the pathogenesis of CKD is widely appreciated, in large measure because of experimental studies conducted in the 1980s [39]. Ang II has emerged as a central mediator of renal injury because of its ability to produce glomerular capillary hypertension that results in damage to glomerular epithelial, endothelial, and mesangial cells [30, 39]. Furthermore, Ang II and aldosterone have several non-hemodynamic effects that are also important in the pathogenesis of CKD, including activation of pathways associated with inflammation, fibrosis, extracellular matrix accumulation, reactive oxygen species, and endothelial dysfunction (fig. 1) [30].

A number of kidney diseases are associated with activation of the intrarenal RAAS. Chief among them is diabetic nephropathy [40], which is the most common cause of CKD [41]. Patients with diabetes usually present with normal to low PRA [40]. However, the intrarenal RAAS appears to be activated in these patients, as evidenced by elevated urinary Agt, a presumptive marker of intrarenal RAAS activation $[23,24]$ and by the marked increase in renal blood flow in patients with diabetes in response to an ACE inhibitor or ARB despite low PRA [40].

\section{Blockade of the RAAS in CKD}

Perhaps the best evidence implicating activation of the RAAS in CKD comes from clinical trials showing unequivocal benefits of RAAS blockade on the progression of CKD. Thus, ACE inhibitors and ARBs provide protection against the progressive loss of renal function in diabetic and non-diabetic patients with CKD [42-45]. Based on these results, current treatment guidelines recommend ACE inhibitors and ARBs as first-line therapy for CKD [41].

However, inhibition of the RAAS with ACE inhibitors and ARBs has not produced the level of cardiorenal protection that might be expected by inhibiting a system that is so intimately linked to the pathogenesis of CKD, and many patients still progress to end-stage renal disease (ESRD) or die from cardiovascular causes (fig. 2) [44, 45]. A possible reason for this is that by inhibiting the formation or action of Ang II, both ACE inhibitors and ARBs cause a compensatory increase in PRA due to interruption of the short negative feedback loop by which Ang II inhibits renin release. Accordingly, new treatment strategies are being tested that should increase the suppression of the RAAS and may improve renal protection. These include high-dose ARB or ACE inhibitor treatment, ACE inhibitor-ARB combination therapy, and direct renin inhibition.

\section{High-Dose ARB or ACE Inhibitor Therapy}

Only one study has examined the effects of high doses of ARBs or ACE inhibitors on renal outcomes. In an open-label study of 360 non-diabetic patients with proteinuria and chronic renal insufficiency (the Renoprotection of Optimal Antiproteinuric Doses (ROAD) Study) [46], optimal antiproteinuric doses of benazepril (up to 40 $\mathrm{mg}$ ) or losartan (up to $200 \mathrm{mg}$ ) were associated with a 51 and $53 \%$ reduction in the risk for the composite endpoint of time to doubling of serum creatinine, ESRD, or death ( $\mathrm{p}=0.028$ and 0.022 , respectively) when compared with conventional doses of $10 \mathrm{mg}$ benazepril and $50 \mathrm{mg}$ losartan. Additional long-term trials are needed to confirm the safety and efficacy of high-dose ACE inhibitor or $\mathrm{ARB}$ therapy on renal outcomes in CKD.

\section{ACE Inhibitor-ARB Combination Therapy}

Studies that have evaluated the effects of ACE inhibitor-ARB combination therapy on the progression of CKD have been of small size and short duration and have used proteinuria as a surrogate marker of renal protection. Nevertheless, a recent meta-analysis concluded that ACE 


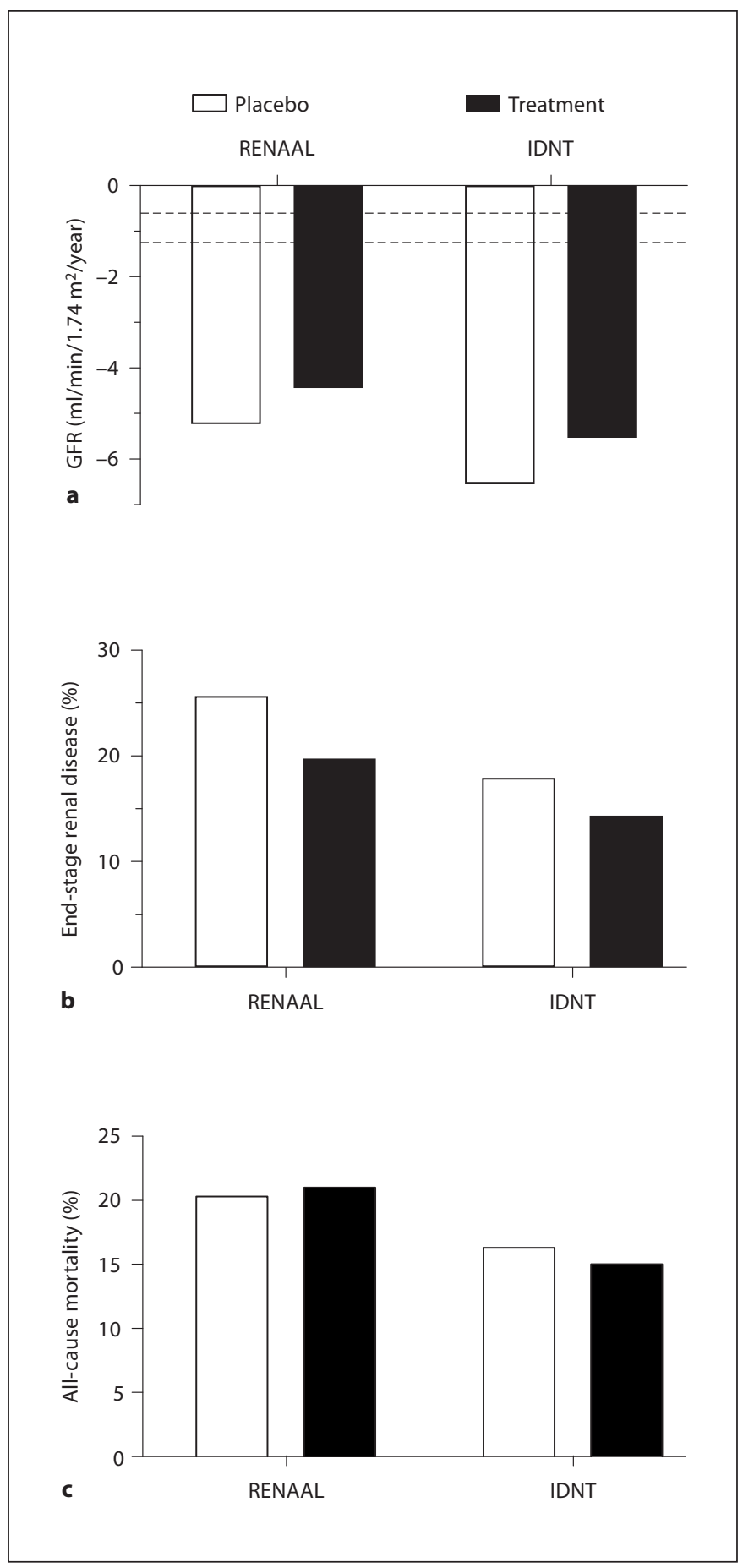

Fig. 2. Effects of angiotensin receptor blockers on chronic kidney disease progression in patients with type 2 diabetic nephropathy. a Estimated decline in glomerular filtration rate (GFR) in patients receiving placebo or treatment with losartan (Reduction of Endpoints in NIDDM With the Angiotensin II Antagonist Losartan [RENAAL]) or irbesartan (Irbesartan in Diabetic Nephropathy Trial [IDNT]). Broken lines represent the range of normal decline in GFR due to aging [49]. b Proportion of patients progressing to end-stage renal disease. c Mortality rates [data from 44, 45].
inhibitor-ARB combination therapy reduces proteinuria to a greater extent than ACE inhibitor or ARB monotherapy in patients with diabetic and non-diabetic nephropathy [47]. However, the recently reported results of a prespecified analysis of renal outcomes in the large Ongoing Telmisartan Alone and in Combination With Ramipril Global Endpoint Trial (ONTARGET) [48] found that ramipril-telmisartan combination therapy decreased proteinuria compared with ramipril alone but worsened the primary renal composite endpoint of dialysis, doubling of serum creatinine, and death when compared with the component monotherapy in patients at high vascular risk. These results have provoked a lively debate on the role of ACE inhibitor-ARB combination therapy in CKD [49]. However, as has been pointed out, ONTARGET was not powered to detect differences in major renal outcomes, and macroalbuminuria was present in only $4 \%$ of all patients and in only $12.2 \%$ of patients with diabetes at study entry [48]. In addition, the rate of decline over the course of the study in estimated glomerular filtration rate in the combination therapy group was in the range associated with normal aging [49]. Although ramipriltelmisartan combination therapy may have no benefits in high-risk patients without proteinuria, it is not known whether this applies to all ACE inhibitor-ARB combinations. Furthermore, this trial did not address the efficacy of ACE inhibitor-ARB combination therapy on renal outcomes in patients with chronic proteinuric kidney disease. Two trials are currently underway, the Nephropathy inDiabetesStudy(VANEPHRON-DStudy,NCT00555217) and Preventing ESRD in Overt Nephropathy of Type 2 Diabetes (VALID, NCT00494715), which are evaluating ACE inhibitor-ARB combinations for renoprotection in patients with type 2 diabetic nephropathy using clinical endpoints such as progression to ESRD and death.

\section{Direct Renin Inhibition}

Aliskiren is the first orally active DRI to receive regulatory approval for hypertension. By inhibiting the enzymatic conversion by renin of Agt to Ang I, DRIs inhibit the initial and rate-limiting step in the RAAS cascade, thus reducing the production of all downstream products derived from Agt [50, 51]. Furthermore, in both clinical studies [52] and in experimental animals [14], aliskiren reduces plasma and/or urinary excretion of aldosterone. The role of aldosterone in endothelial dysfunction, inflammation, proteinuria and fibrosis is well known [30]. Most notable are the observations of additional antiproteinuric effects when mineralocorticoid receptor blockers are added to ACE inhibitor or ARB therapy in patients 
with CKD [31]. Therefore, aliskiren's ability to lower aldosterone levels may provide additional renoprotective effects.

Further potential benefits of renin inhibition are suggested by the observation that in healthy individuals on a low-sodium diet, aliskiren induced long-lasting renal vasodilation that far exceeded that seen with ACE inhibitors or ARBs, which was observed at a time postdose when plasma levels of the drug were undetectable [53]. This may be related to experimental findings that aliskiren localizes to kidneys and binds to both renin and prorenin [54]. In hypertensive diabetic rat models with kidney damage, aliskiren reduced blood pressure, proteinuria, and measures of kidney fibrosis and inflammation (table 1) [54-57]. Taken together, these data suggest that aliskiren induces an effective blockade of the intrarenal RAAS.

The mechanisms by which aliskiren may impart renoprotection are still under investigation. However, a number of possible mechanisms can be envisioned. First, aliskiren not only inhibits renin but also inhibits the activity of prorenin [54] following its non-proteolytic activation upon binding to the (pro)renin receptor [12]. This may be of particular importance in diabetes in which prorenin levels are elevated and may contribute to local Ang II formation [14]. Second, aliskiren blocks the circulating RAAS and lowers blood pressure [58]. Hypertension is one of the most common comorbidities in CKD and its control is essential in reducing further renal damage and cardiovascular risk in CKD patients [41]. Third, aliskiren blocks the intrarenal RAAS and lowers renal Ang I and Ang II levels [55], thus reducing the deleterious renal effects of Ang II [30] (fig. 1). Finally, aliskiren has been shown to reduce the renal expression of the (pro)renin receptor in an animal model of diabetes [54]. If the (pro)renin receptor plays a role in $\mathrm{CKD}$, downregulation of this receptor may reduce the Ang II-independent effects of (pro)renin receptor activation on renal fibrotic pathways [13] (fig. 1).

Although aliskiren has been shown to be an effective and long-acting antihypertensive agent when used as monotherapy or in combination with other antihypertensive drugs [58], only three studies have evaluated aliskiren as a potential renoprotective agent in CKD (table 2). All studies used proteinuria as a surrogate marker of CKD progression. In a small open-label exploratory study, patients with type 2 diabetes and proteinuria received aliskiren $(300 \mathrm{mg} /$ day $)$ and furosemide but no other RAAS blockers for 4 weeks [50]. At study end, the urinary albumin/creatine ratio (UACR) had decreased by
Table 1. Preclinical studies of aliskiren in models of kidney damage

\begin{tabular}{lll}
\hline Study & Model & Aliskiren effects \\
\hline $\begin{array}{l}\text { Pilz } \\
\text { et al. [55] }\end{array}$ & $\begin{array}{l}\text { double trans- } \\
\text { genic rat } \\
\text { (dTGR) }\end{array}$ & $\begin{array}{l}\text { decreased mortality, decreased } \\
\text { BP, albuminuria, and serum } \\
\text { creatinine }\end{array}$ \\
\hline $\begin{array}{l}\text { Shagdarsuren } \\
\text { et al. [57] }\end{array}$ & $\begin{array}{l}\text { double trans- } \\
\text { genic rat } \\
\text { (dTGR) }\end{array}$ & $\begin{array}{l}\text { decreased BP, albuminuria, } \\
\text { serum creatinine, renal fibro- } \\
\text { sis, TNF- } \alpha \text {, cell infiltration, } \\
\text { and complement activation }\end{array}$ \\
\hline $\begin{array}{l}\text { Kelly } \\
\text { et al. [56] }\end{array}$ & $\begin{array}{l}\text { diabetic trans- } \\
\text { genic rats } \\
\text { (mRen-2)27 }\end{array}$ & $\begin{array}{l}\text { decreased BP, albuminuria, } \\
\text { interstitial fibrosis, and } \\
\text { glomerulosclerosis }\end{array}$ \\
\hline $\begin{array}{l}\text { Feldman } \\
\text { et al. [54] }\end{array}$ & $\begin{array}{l}\text { diabetic trans- } \\
\text { genic rats } \\
\text { (mRen-2)27 }\end{array}$ & $\begin{array}{l}\text { decreased BP, albuminuria, } \\
\text { TGF- } \beta \text {, and collagen I } \\
\text { expression }\end{array}$ \\
\hline
\end{tabular}

TGF- $\beta=$ Transforming growth factor $\beta$; TNF- $\alpha=$ tumor necrosis factor $\alpha$.

$44 \%$ from baseline $(\mathrm{p}<0.001)$ and remained below baseline for 12 days following washout. PRA was reduced by $68 \%(\mathrm{p}<0.001)$ and Ang II by $42 \%(\mathrm{p}=0.044)$ at the end of the treatment period. PRA and Ang II only gradually returned to baseline during a 4-week washout period, which is evidence of aliskiren's long duration of action [53]. In another small randomized crossover trial [51], patients $(\mathrm{n}=26)$ with type 2 diabetes and proteinuria were randomized to receive placebo, aliskiren $300 \mathrm{mg}$, irbesar$\tan 300 \mathrm{mg}$, or a combination of aliskiren $300 \mathrm{mg}$ and irbesartan $300 \mathrm{mg}$ for 2 months. Aliskiren treatment resulted in a significant $48 \%(\mathrm{p}<0.001)$ reduction in urinary albumin excretion compared with placebo. Irbesartan reduced albumin excretion by $58 \%$ ( $p<0.001$ vs. placebo) which was not different from aliskiren. The combination of aliskiren/irbesartan reduced albumin excretion by $71 \%$ ( $p<0.001$ vs. placebo), which was significantly more than with aliskiren $(\mathrm{p}<0.001)$ or irbesartan monotherapy $(\mathrm{p}=0.028)$.

In the Aliskiren in the Evaluation of Proteinuria in Diabetes (AVOID) Trial [59], patients $(n=599)$ with type 2 diabetic nephropathy received a 6-month treatment with aliskiren (150 mg/day for 3 months, then $300 \mathrm{mg} /$ day for 3 months) or placebo in combination with losar$\tan (100 \mathrm{mg} /$ day). After 3 months of treatment, UACR had decreased by $11 \%$ compared with losartan alone $(\mathrm{p}=$ 0.02). Increasing the dose of aliskiren to $300 \mathrm{mg} /$ day caused a further decrease in UACR to $20 \%(\mathrm{p}<0.001)$ by 
Table 2. Clinical trials of aliskiren in patients with type 2 diabetes and proteinuria

\begin{tabular}{|c|c|c|c|c|}
\hline Study design & Population & Treatment & Outcome & Reference \\
\hline $\begin{array}{l}\text { Open-label, single- } \\
\text { center }(\mathrm{n}=15)\end{array}$ & $\begin{array}{l}\text { mean age } 63.5 \text { years, } 87 \% \text { male, } \\
100 \% \text { white, UACR } 173 \mathrm{mg} / \mathrm{g}, \\
24 \mathrm{~h} \mathrm{maBP} 143 / 75 \mathrm{~mm} \mathrm{Hg}\end{array}$ & $300 \mathrm{mg}$ aliskiren for 28 days & $\begin{array}{l}\text { UACR decreased by } 44 \% \text { vs. } \\
\text { baseline }(\mathrm{p}<0.001) \\
\text { maBP decreased }(\mathrm{p}=0.035)\end{array}$ & $\begin{array}{l}\text { Persson } \\
\text { et al. [50] }\end{array}$ \\
\hline $\begin{array}{l}\text { Randomized, double- } \\
\text { blind, multicenter } \\
(\mathrm{n}=599)\end{array}$ & $\begin{array}{l}\text { mean age } 59.8-61.8 \text { years, } \\
68.4-74.2 \% \text { male, } 86.0-87.6 \% \\
\text { white, UACR } 513-553 \mathrm{mg} / \mathrm{g}\end{array}$ & $\begin{array}{l}\text { losartan } 100 \mathrm{mg} \text { vs. losartan } 100 \mathrm{mg} \\
\text { and aliskiren } 150 \mathrm{mg} \text { for } 3 \text { months } \\
\text { titrated to } 300 \mathrm{mg} \text { for } 3 \text { months }\end{array}$ & $\begin{array}{l}\text { UACR decreased by } 20 \% \text { with } \\
\text { aliskiren/losartan vs. losartan } \\
(\mathrm{p}<0.0001) \text { with no significant } \\
\text { differences in BP }\end{array}$ & $\begin{array}{l}\text { AVOID } \\
\text { Trial } \\
\text { Parving } \\
\text { et al. [59] }\end{array}$ \\
\hline $\begin{array}{l}\text { Randomized, double- } \\
\text { blind, crossover, } \\
\text { single-center }(\mathrm{n}=26)\end{array}$ & $\begin{array}{l}\text { mean age } 59.8 \text { years, } 77 \% \text { male, } \\
100 \% \text { white, UAER } 275 \mathrm{mg} / \text { day }\end{array}$ & $\begin{array}{l}\text { placebo, } 300 \mathrm{mg} \text { aliskiren, } \\
300 \mathrm{mg} \text { irbesartan or } 300 \mathrm{mg} \text { aliskiren/ } \\
300 \mathrm{mg} \text { irbesartan for } 2 \text { months }\end{array}$ & $\begin{array}{l}\text { change in UAER (\%) vs. placebo } \\
\text { aliskiren - } 48 \% \text {, irbesartan -58\% } \\
\text { aliskiren/irbesartan }-71 \%\end{array}$ & $\begin{array}{l}\text { Persson } \\
\text { et al. [51] }\end{array}$ \\
\hline
\end{tabular}

$\mathrm{BP}=$ Blood pressure; $\mathrm{maBP}=$ mean ambulatory blood pressure; $\mathrm{UACR}=$ urinary albumin creatinine ratio; UAER = urinary albumin excretion rate.

the end of the study. The effects of the combination of aliskiren and losartan on UACR appeared to be independent of blood pressure changes. There was no difference in the rates of adverse events or discontinuation rates between the two groups. Hyperkalemia was reported in $5.0 \%$ of the patients in the aliskiren group and $5.7 \%$ in the placebo group.

These initial studies suggest that direct renin inhibition may offer an additional treatment option in patients with type 2 diabetes and nephropathy, but larger longterm trials that measure renal outcomes such as progression to ESRD and mortality are needed. One such trial (Aliskiren Trial in Type 2 Diabetic Nephropathy [ALTITUDE]) is ongoing and may determine whether aliskiren in combination with an ACE inhibitor or ARB reduces endpoints of cardiorenal morbidity and mortality in high-risk patients with type 2 diabetes [60].

\section{Summary and Conclusions}

Sustained activation of the intrarenal RAAS in the presence of elevated arterial pressure leads to renal injury and plays a pivotal role in the pathogenesis of CKD. Blockade of the RAAS with ACE inhibitors or ARBs decreases the decline in glomerular filtration rate, but many patients still progress to ESRD and remain at high risk for fatal or non-fatal cardiovascular events. More aggressive blockade of the RAAS with high-dose ACE inhibitors and ARBs or therapy with ACE inhibitor-ARB combinations have been shown to further reduce proteinuria in patients with diabetic and non-diabetic nephropathy. However, RAAS blockade with these treatment regimens may be incomplete because both $\mathrm{ACE}$ inhibitors and $\mathrm{ARBs}$ cause a compensatory increase in PRA and Ang II. DRIs directly inhibit renin and the subsequent formation of downstream products of the RAAS. Initial studies in patients with type 2 diabetic nephropathy have shown that aliskiren alone or in combination with an ARB decreases protein excretion and may have a renoprotective effect independent of blood pressure in patients receiving optimal antihypertensive therapy. Longer-term trials are underway with ACE inhibitor-ARB combinations, ACE inhibitor-aliskiren combinations, and $\mathrm{ARB}$-aliskiren combinations in attempts to decrease renal and cardiovascular morbidity and mortality in high-risk patients with type 2 diabetic nephropathy.

Although it has been more than 100 years since the discovery of renin, the RAAS continues to occupy a central position in the research of cardiovascular and renal pathophysiology. The clinical success of ACE inhibitors and ARBs will likely continue in the form of new drugs, combinations, and therapeutic strategies as new therapeutic targets within the RAAS are identified.

\section{Acknowledgments}

Editorial assistance was provided by Richard M. Edwards, $\mathrm{PhD}$, Complete Healthcare Communications, Inc., and was funded by Novartis Pharmaceuticals Corp.

\section{Conflicts of Interest}

Dr. Siragy received research grants from Novartis Pharmaceuticals Corp. Dr. Carey serves on advisory boards for Novartis, Daiichi Sankyo and Takeda. 


\section{References}

1 Kobori H, Nangaku M, Navar LG, Nishiyama A: The intrarenal renin-angiotensin system: from physiology to the pathobiology of hypertension and kidney disease. Pharmacol Rev 2007;59:251-287.

$\checkmark 2$ Kimbrough HM Jr, Vaughan ED Jr, Carey RM, Ayers CR: Effect of intrarenal angiotensin II blockade on renal function in conscious dogs. Circ Res 1977;40:174-178.

$\checkmark 3$ Atlas SA: The renin-angiotensin aldosterone system: pathophysiological role and pharmacologic inhibition. J Manag Care Pharm 2007;13:9-20

4 Carey RM, Wang ZQ, Siragy HM: Role of the angiotensin type 2 receptor in the regulation of blood pressure and renal function. Hypertension 2000;35:155-163.

$\checkmark 5$ Wagner C: Function of connexins in the renal circulation. Kidney Int 2008;73:547-555.

-6 Hanner F, von Maltzahn J, Maxeiner S, Toma I, Sipos A, Kruger O, Willecke K, Peti-Peterdi J: Connexin45 is expressed in the juxtaglomerular apparatus and is involved in the regulation of renin secretion and blood pressure. Am J Physiol 2008;295:R371-R380.

-7 Kang JJ, Toma I, Sipos A, Meer EJ, Vargas SL, Peti-Peterdi J: The collecting duct is the major source of prorenin in diabetes. Hypertension 2008;51:1597-1604.

$\checkmark 8$ Prieto-Carrasquero MC, Kobori H, Ozawa Y, Gutierrez A, Seth D, Navar LG: $\mathrm{AT}_{1}$ receptor-mediated enhancement of collecting duct renin in angiotensin II-dependent hypertensive rats. Am J Physiol Renal Physiol 2005;289:F632-F637.

$9 \mathrm{He}$ W, Miao FJ, Lin DC, Schwandner RT, Wang Z, Gao J, Chen JL, Tian H, Ling L: Citric acid cycle intermediates as ligands for orphan G-protein-coupled receptors. Nature 2004;429:188-193.

-10 Toma I, Kang JJ, Sipos A, Vargas S, Bansal E, Hanner F, Meer E, Peti-Peterdi J: Succinate receptor GPR91 provides a direct link between high glucose levels and renin release in murine and rabbit kidney. J Clin Invest 2008; 118:2526-2534.

-11 Nguyen G, Delarue F, Burckle C, Bouzhir L, Giller T, Sraer JD: Pivotal role of the renin/ prorenin receptor in angiotensin II production and cellular responses to renin. J Clin Invest 2002;109:1417-1427.

12 Danser AH: The increase in renin during renin inhibition: does it result in harmful effects by the (pro)renin receptor? Hypertens Res 2010;33:4-10.

13 Huang Y, Wongamorntham S, Kasting J, McQuillan D, Owens RT, Yu L, Noble NA, Border W: Renin increases mesangial cell transforming growth factor- $\beta_{1}$ and matrix proteins through receptor-mediated, angiotensin II-independent mechanisms. Kidney Int 2006;69:105-113.
4 Feldman DL: New insights into the renoprotective actions of the renin inhibitor aliskiren in experimental renal disease. Hypertens Res 2010;33:279-287.

15 Sakoda M, Ichihara A, Kurauchi-Mito A, Narita T, Kinouchi K, Murohashi-Bokuda K, Saleem MA, Nishiyama A, Suzuki F, Itoh H: Aliskiren inhibits intracellular angiotensin II levels without affecting (pro)renin receptor signals in human podocytes. Am J Hypertens 2010;23:575-580.

16 Schefe JH, Menk M, Reinemund J, Effertz K, Hobbs RM, Pandolfi PP, Ruiz P, Unger T, Funke-Kaiser $\mathrm{H}$ : A novel signal transduction cascade involving direct physical interaction of the renin/prorenin receptor with the transcription factor promyelocytic zinc finger protein. Circ Res 2006;99:1355-1366.

17 Burckle CA, Jan Danser AH, Muller DN, Garrelds IM, Gasc JM, Popova E, Plehm R, Peters J, Bader M, Nguyen G: Elevated blood pressure and heart rate in human renin receptor transgenic rats. Hypertension 2006; 47:552-556.

18 Peters B, Grisk O, Becher B, Wanka H, Kuttler B, Ludemann J, Lorenz G, Rettig R, Mullins JJ, Peters J: Dose-dependent titration of prorenin and blood pressure in Cypla1ren-2 transgenic rats: absence of prorenin-induced glomerulosclerosis. J Hypertens 2008;26: 102-109.

19 Mercure C, Prescott G, Lacombe MJ, Silversides DW, Reudelhuber TL: Chronic increases in circulating prorenin are not associated with renal or cardiac pathologies. Hypertension 2009;53:1062-1069.

20 Kaneshiro Y, Ichihara A, Sakoda M, Takemitsu T, Nabi AH, Uddin MN, Nakagawa T, Nishiyama A, Suzuki F, Inagami T, Itoh H: Slowly progressive, angiotensin II-independent glomerulosclerosis in human (pro)renin receptor-transgenic rats. J Am Soc Nephrol 2007;18:1789-1795.

21 Kobori H, Ozawa Y, Suzaki Y, Prieto-Carrasquero MC, Nishiyama A, Shoji T, Cohen EP, Navar LG: Young Scholars Award Lecture: Intratubular angiotensinogen in hypertension and kidney diseases. Am J Hypertens 2006;19:541-550.

-22 Saito T, Urushihara M, Kotani Y, Kagami S, Kobori H: Increased urinary angiotensinogen is precedent to increased urinary albumin in patients with type 1 diabetes. Am J Med Sci 2009;338:478-480.

23 Kobori H, Alper AB Jr, Shenava R, Katsurada A, Saito T, Ohashi N, Urushihara M, Miyata K, Satou R, Hamm LL, Navar LG: Urinary angiotensinogen as a novel biomarker of the intrarenal renin-angiotensin system status in hypertensive patients. Hypertension 2009;53:344-350.
24 Yamamoto T, Nakagawa T, Suzuki H, Ohashi N, Fukasawa H, Fujigaki Y, Kato A, Nakamura Y, Suzuki F, Hishida A: Urinary angiotensinogen as a marker of intrarenal angiotensinIIactivityassociated with deterioration of renal function in patients with chronic kidney disease. J Am Soc Nephrol 2007;18: 1558-1565.

25 Huang XR, Chen WY, Truong LD, Lan HY: Chymase is upregulated in diabetic nephropathy: implications for an alternative pathway of angiotensin II-mediated diabetic renal and vascular disease. J Am Soc Nephrol 2003; 14:1738-1747.

26 Tipnis SR, Hooper NM, Hyde R, Karran E, Christie G, Turner AJ: A human homolog of angiotensin-converting enzyme. Cloning and functional expression as a captopril-insensitive carboxypeptidase. J Biol Chem 2000;275:33238-33243.

27 Ferrario CM: Angiotensin-converting enzyme 2 and angiotensin-(1-7): an evolving story in cardiovascular regulation. Hypertension 2006;47:515-521.

28 Ye M, Wysocki J, William J, Soler MJ, Cokic I, Batlle D: Glomerular localization and expression of angiotensin-converting enzyme 2 and angiotensin-converting enzyme: implications for albuminuria in diabetes. J Am Soc Nephrol 2006;17:3067-3075.

$>29$ Wong DW, Oudit GY, Reich H, Kassiri Z, Zhou J, Liu QC, Backx PH, Penninger JM, Herzenberg AM, Scholey JW: Loss of angiotensin-converting enzyme-2 (Ace2) accelerates diabetic kidney injury. Am J Pathol 2007;171:438-451.

-30 Ruster C, Wolf G: Renin-angiotensin-aldosterone system and progression of renal disease. J Am Soc Nephrol 2006;17:2985-2991.

-31 Bomback AS, Kshirsagar AV, Amamoo MA, Klemmer PJ: Change in proteinuria after adding aldosterone blockers to ACE inhibitors or angiotensin receptor blockers in CKD: a systematic review. Am J Kidney Dis 2008;51:199-211.

32 Xue C, Siragy HM: Local renal aldosterone system and its regulation by salt, diabetes, and angiotensin II type 1 receptor. Hypertension 2005;46:584-590.

$\checkmark 33$ Lee SH, Yoo TH, Nam BY, Kim DK, Li JJ, Jung DS, Kwak SJ, Ryu DR, Han SH, Lee JE, Moon SJ, Han DS, Kang SW: Activation of local aldosterone system within podocytes is involved in apoptosis under diabetic conditions. Am J Physiol Renal Physiol 2009; 297:F1381-F1390.

34 Draper N, Stewart PM: 11 $\beta$-Hydroxysteroid dehydrogenase and the pre-receptor regulation of corticosteroid hormone action. J Endocrinol 2005;186:251-271.

>35 Kyossev Z, Walker PD, Reeves WB: Immunolocalization of NAD-dependent $11 \beta$-hydroxysteroid dehydrogenase in human kidney and colon. Kidney Int 1996;49:271-281. 
36 Ferrari P, Krozowski Z: Role of the 11ß-hydroxysteroid dehydrogenase type 2 in blood pressure regulation. Kidney Int 2000;57: 1374-1381.

- 37 Lanz B, Kadereit B, Ernst S, Shojaati K, Causevic M, Frey BM, Frey FJ, Mohaupt MG: Angiotensin II regulates $11 \beta$-hydroxysteroid dehydrogenase type 2 via $\mathrm{AT}_{2}$ receptors. Kidney Int 2003;64:970-977.

- 38 Kerstens MN, van der Kleij FG, Boonstra AH, Sluiter WJ, van der Molen JC, Navis G, Dullaart RP: Angiotensin administration stimulates renal $11 \beta$-hydroxysteroid dehydrogenase activity in healthy men. Kidney Int 2004;65:2065-2070.

-39 Anderson S, Rennke HG, Brenner BM: Therapeutic advantage of converting enzyme inhibitors in arresting progressive renal disease associated with systemic hypertension in the rat. J Clin Invest 1986;77:1993-2000.

-40 Hollenberg NK, Price DA, Fisher ND, Lansang MC, Perkins B, Gordon MS, Williams GH, Laffel LM: Glomerular hemodynamics and the renin-angiotensin system in patients with type 1 diabetes mellitus. Kidney Int 2003;63:172-178.

-41 KDOQI Clinical Practice Guidelines and Clinical Practice Recommendations for Diabetes and Chronic Kidney Disease. Am J Kidney Dis 2007;49:S12-S154.

42 Lewis EJ, Hunsicker LG, Bain RP, Rohde RD: The effect of angiotensin-converting-enzyme inhibition on diabetic nephropathy. The Collaborative Study Group. N Engl J Med 1993;329:1456-1462.

-43 GISEN Group: Randomised placebo-controlled trial of effect of ramipril on decline in glomerular filtration rate and risk of terminal renal failure in proteinuric, non-diabetic nephropathy. The GISEN Group (Gruppo Italiano di Studi Epidemiologici in Nefrologia). Lancet 1997;349:1857-1863.

-44 Lewis EJ, Hunsicker LG, Clarke WR, Berl T, Pohl MA, Lewis JB, Ritz E, Atkins RC, Rohde $\mathrm{R}, \mathrm{Raz}$ I: Renoprotective effect of the angiotensin-receptor antagonist irbesartan in patients with nephropathy due to type 2 diabetes. N Engl J Med 2001;345:851-860.
45 Brenner BM, Cooper ME, de Zeeuw D, Keane WF, Mitch WE, Parving $\mathrm{HH}, \mathrm{Re}-$ muzzi G, Snapinn SM, Zhang Z, Shahinfar S: Effects of losartan on renal and cardiovascular outcomes in patients with type 2 diabetes and nephropathy. N Engl J Med 2001;345: 861-869.

46 Hou FF, Xie D, Zhang X, Chen PY, Zhang WR, Liang M, Guo ZJ, Jiang JP: Renoprotection of Optimal Antiproteinuric Doses (ROAD) Study: a randomized controlled study of benazepril and losartan in chronic renal insufficiency. J Am Soc Nephrol 2007; 18:1889-1898.

-47 Kunz R, Friedrich C, Wolbers M, Mann JF: Meta-analysis: effect of monotherapy and combination therapy with inhibitors of the renin angiotensin system on proteinuria in renal disease. Ann Intern Med 2008;148:30 48.

48 Mann JF, Schmieder RE, McQueen M, Dyal L, Schumacher H, Pogue J, Wang X, Maggioni A, Budaj A, Chaithiraphan S, Dickstein K, Keltai M, Metsarinne K, Oto A, Parkhomenko A, Piegas LS, Svendsen TL, Teo KK, Yusuf S: Renal outcomes with telmisartan, ramipril, or both, in people at high vascular risk (the ONTARGET study): a multicentre, randomised, double-blind, controlled trial. Lancet 2008;372:547-553.

49 Sarafidis PA, Bakris GL: Renin-angiotensin blockade and kidney disease. Lancet 2008; 372:511-512.

50 Persson F, Rossing P, Schjoedt KJ, Juhl T, Tarnow L, Stehouwer CD, Schalkwijk C Boomsma F, Frandsen E, Parving HH: Time course of the antiproteinuric and antihypertensive effects of direct renin inhibition in type 2 diabetes. Kidney Int 2008;73:1419_ 1425.

51 Persson F, Rossing P, Reinhard H, Juhl T, Stehouwer CD, Schalkwijk C, Danser AH, Boomsma F, Frandsen E, Parving HH: Renal effects of aliskiren compared with and in combination with irbesartan in patients with type 2 diabetes, hypertension, and albuminuria. Diabetes Care 2009;32:1873-1879.
52 Yarows SA: Aliskiren/valsartan combination for the treatment of cardiovascular and renal diseases. Expert Rev Cardiovasc Ther 2010;8:19-33

53 Fisher ND, Jan Danser AH, Nussberger J, Dole WP, Hollenberg NK: Renal and hormonal responses to direct renin inhibition with aliskiren in healthy humans. Circulation 2008;117:3199-3205.

54 Feldman DL, Jin L, Xuan H, Contrepas A, Zhou Y, Webb RL, Mueller DN, Feldt S, Cumin F, Maniara W, Persohn E, Schuetz H, Jan Danser AH, Nguyen G: Effects of aliskiren on blood pressure, albuminuria, and (pro)renin receptor expression in diabetic TG(mRen-2)27 rats. Hypertension 2008;52: 130-136.

55 Pilz B, Shagdarsuren E, Wellner M, Fiebeler A, Dechend R, Gratze P, Meiners S, Feldman DL, Webb RL, Garrelds IM, Jan Danser AH, Luft FC, Muller DN: Aliskiren, a human renin inhibitor, ameliorates cardiac and renal damage in double-transgenic rats. Hypertension 2005;46:569-576.

56 Kelly DJ, Zhang Y, Moe G, Naik G, Gilbert RE: Aliskiren, a novel renin inhibitor, is renoprotective in a model of advanced diabetic nephropathy in rats. Diabetologia 2007; 50:2398-2404

-57 Shagdarsuren E, Wellner M, Braesen JH, Park JK, Fiebeler A, Henke N, Dechend R, Gratze P, Luft FC, Muller DN: Complement activation in angiotensin II-induced organ damage. Circ Res 2005;97:716-724.

58 Pimenta E, Oparil S: Role of aliskiren in cardiorenal protection and use in hypertensives with multiple risk factors. Ther Clin Risk Manag 2009;5:459-464.

59 Parving HH, Persson F, Lewis JB, Lewis EJ, Hollenberg NK: Aliskiren combined with losartan in type 2 diabetes and nephropathy. N Engl J Med 2008;358:2433-2446.

60 Parving HH, Brenner BM, McMurray JJ, de Zeeuw D, Haffner SM, Solomon SD, Chaturvedi N, Ghadanfar M, Weissbach N, Xiang Z, Armbrecht J, Pfeffer MA: Aliskiren Trial in Type 2 Diabetic Nephropathy (ALTITUDE): rationale and study design. Nephrol Dial Transplant 2009;24:1663-1671. 